\title{
Rebranding and Purchase Intention on King Thai Tea
}

\author{
Heny Hendrayati, Ratih Hurriyati, Cipto Putra Daud \\ Department of Management Faculty of Economics and Business Education \\ Universitas Pendidikan Indonesia, Bandung, Indonesia \\ henyhendrayati@upi.edu
}

\begin{abstract}
The rapid development of the food and beverage industry MSMEs sector creates great opportunities for entrepreneurs. One of them Thai Tea is emerging discussed being targeted businesses to get involved that led to keen competition. The purpose of the research is to describe the rebranding conducted by King Thai Tea and purchase intention as well as the influence of rebranding conducted by King Thai Tea on purchase intention. This study used descriptive and verification methods. Samples taken were 170 respondents. The sampling technique used is probability sampling. Data analysis technique used is the Pearson product moment correlation coefficient and simple linear regression analysis. Hypothesis test used t-test to view the partial effect. The results of this study indicate that the rebranding and purchase intention in the high category on the continuum line. The results of the correlation calculations, rebranding variables have a significant influence on purchase intention.
\end{abstract}

Keywords - Rebranding, Purchase Intention, AIDA

\section{INTRODUCTION}

Food and beverage industry Indonesia plays an important role in the Indonesian economy. Growth reached $8.16 \%$ (Ministry of Industry, 2015) is expected to prop overall industry growth. However food and beverage industry growth rate will be more severe when confronted with MEA (Asian Economic Community), the economic crisis (weak IDR), the policy of the rise and fall of fuel prices, and other issues that interfere with the stability of the domestic trade sector. Alternative solution to this problem is the Micro Small and Medium Enterprises (MSMEs) which proved resilient to the economic crisis [1].

Food and beverage industry MSMEs sector offers a wide variety of consumer products to choose from, one of them is tea. Looking at business development bottled tea beverages (ready to drink) is growing rapidly with a percentage of $49 \%$ is only $57 \%$ less than the coffee and isotonic 52\% (Kantar Wordpanel, 2014) has become a new field for business operators [2].

A new trend where Thai Tea public interest Indonesia lately in particular young people in the city because of a distinctive taste and unique. Businesses saw a new business opportunity that is profitable, and King Thai Tea present of many businesses which offer tea products Thailand [3].

The positive trend of Thai Tea is not currently become a benchmark that on average businesses in this field are in a positive trend as well, because not only King Thai Tea is involved in this market, there are a lot of competitors or other businesses already involved first past or emerging with the aim of vying with each other to attract consumers to buy [4].

Researchers conducted a pre-research to 30 students actively Department of Management UPI Bandung who participated in Kamis Senja IMAGE UPI event collaboration with King Thai Tea got a result that as many as $50 \%$ of respondents chose Addic'tea as brand Thai Tea was first on their minds, followed by King Thai Tea (33\%), Mimichan $(10 \%)$ and SAY Tea (6.7\%). Based on this study, researchers pre-seen any indication that the King Thai Tea has not been so embedded in the minds of respondents.

Increasing number of competitors makes consumers are given a variety of options such as pricing, promotion, flavors and many other forms that can influence consumers before deciding to buy the product. Pre-research survey conducted afterward to find out more about purchase intention King Thai Tea beverage products. Figure 1.1 describes the stages of purchase intention as many as 25 people are in a position less until very not interested in buying the product beverages King Thai Tea, only five people who expressed purchase intention products beverages King Thai Tea.

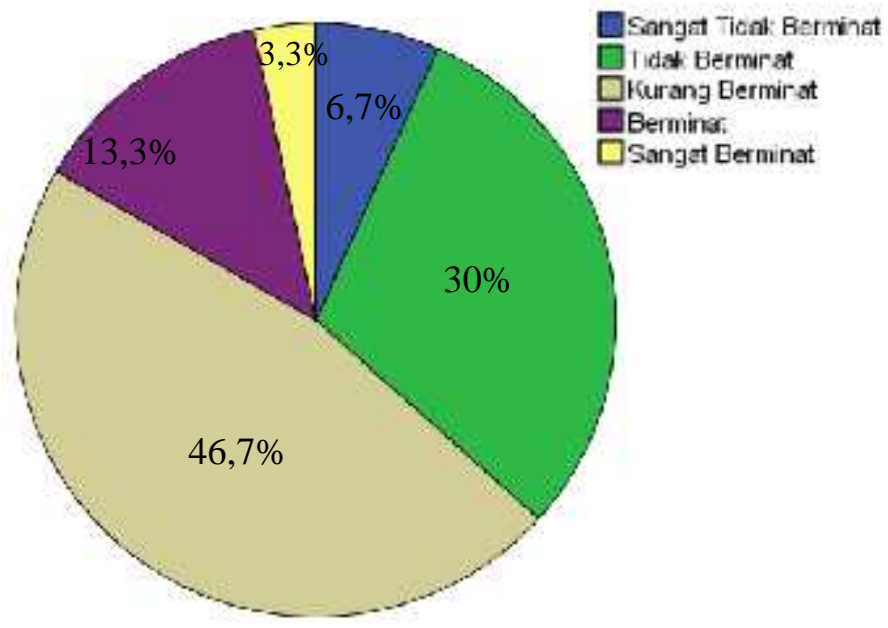

Source: Pre Research, 2016

Fig. 1. 1 Purchase Intention King Thai Tea Beverage Products

Based on the results of this study can be seen pre the indication of the lack of purchase intention King Thai Tea beverage products among the public (consumers) in particular among youth. There are various factors that affect the interests 
of consumer spending, one of the most influential is the brand (brand). As noted Kotler and Keller (2016, p. 198), in the evaluation phase, consumers form brand preference among the collection of choice and can also form an purchase intention the most preferred brand. Consumers can make a decision to implement a backup 5 interest in the purchase include: brand, dealer, quantity, timing, and payment method [5].

There are four stages of the process of rebranding by Muzellec et al. (2003, p. 32) that: repositioning, renaming, redesign, and relaunching. In this case King Thai Tea just three rebranding process including repositioning, redesign, and the relaunching without changing the brand name of King Thai Tea itself (renaming) or can be referred to by evolutionary rebranding by (Muzellec and Lambkin, 2006, p. 805) [6][7].

TABLE I. TOP 10 Most PopUlaR DRINKS IN BANDUNG

\begin{tabular}{|c|c|}
\hline NO RANK & PRODUCT NAME \\
\hline 1 & CAIANS \\
\hline 2 & VIRGIN DRINKS \\
\hline 3 & KIMI KIMI DRINK \\
\hline 4 & COKELAT KOCOK \\
\hline 5 & BLENDONESIA \\
\hline 6 & KEPOKOPI \\
\hline 7 & CALAIS \\
\hline 8 & KING THAI TEA \\
\hline 9 & ADDICTEA \\
\hline 10 & HEAVENS GREEN TEA \\
\hline
\end{tabular}

Source of data: ceritaperut.com, 2015

Viewed Top 10 most popular beverage in Bandung in 2015 (Culinary Directory Indonesia), King Thai Tea is in the order of 8 out of 10 drinks. This data does not reference King Thai in rebranding the brand, but it could be one contributing factor in which brand King Thai Tea has not been heard by the Bandung wider community. The indication of a lack of public awareness of the brand King Thai Tea making power interest in buying the product is not up to also affect the level of product sales that have not been optimized so that the King Thai Tea decide to need rebranding the brand with the hope to increase brand awareness of King Thai Tea in the community and able to affect purchase intention of the community specifically youth in Bandung. Plus a number of new competitors that offer a variety of advantages. King Thai Tea Company has a goal to getting bigger by way of rebranding the brand, then of course the challenge will be getting bigger and more complex [8].

\section{LITERATURE REVIEW}

\section{A. Rebranding}

Brand (brand) is a name, term, sign, symbol, or design, or a combination of all of these are intended to identify products or services of one seller or group and distinguish it from competitors' products. Branding is the central issue in product strategy. Branding was expensive and time-consuming, and can make products succeed or fail. A good brand name can add a great success in the product (Kotler and Armstrong, 2014, p. 257) [9].

Rebranding can mean changing the identification of a business in the eyes of consumers. According Muzellec et al. (2003, p. 32), rebranding consisted of two words ie "re" gives meaning to do for a second time or repetition and "brand". Or it can also be said rebranding as the practice of building a new name representative of differentiated position in the mind frame of stakeholders and a distinctive identity from competitors.

Rebranding can occur at three different levels in the company, namely the corporate level (corporate rebranding), the business unit level (business unit of rebranding) and the level of the product (product rebranding). Rebranding can occur on one level, on two levels, or at all levels, (Muzellec et al., 2003, p. 32).

There are four stages of the process of rebranding by Muzellec et al. (2003, p. 32) that: repositioning, renaming, redesign, and relaunching.

Muzellec and Lambkin (2006, p. 805) suggests, there are two basic dimensions of rebranding, namely: Evolutionary Rebranding explain the development of the relatively small in positioning and aesthetically marketing company difficult to realize by the observer from outside the company, for example by slightly changing the company logo in perspective adjust to the changes. Revolutionary Rebranding describes the identification of a major change in positioning and estesis companies that are fundamentally redefining the company. These changes are usually symbolized by the name change and the variables used as an identifier of the company.

\section{B. Purchase Intention}

According to Kotler and Keller (2012, p. 168), consumers to buy something that arises after receiving the stimulation of the products seen, from there arises the interest to try the product until finally the desire to buy in order to have it [10].

As noted Kotler and Keller (2016, p. 198), in the evaluation phase, consumers form brand preference among the collection of choice and can also form the intention to buy the most preferred brand. The need for a target to be achieved in marketing communications. Marketers must determine responses occurring. The audience response can be either cognitive (awareness stage), affective (stage effect), behavioral/cognitive (action stage of purchase).

There are various models of hierarchical response in the purchase decision process one of them is a model AIDA. There are four steps that experienced by consumers in making purchasing decisions process called AIDA (Attention, Interest, Desire and Action) (Kotler and Keller, 2012, p. 504) [10].

In this study, researchers used the concept of AIDA, attention, interest, and desire is an indicator of consumer purchase intention which describes the stages of stimulation that may be passed by the consumer to the stimulus (stimulus) provided by the company. The disuse of stage action because it is no longer part of the purchase intention due at that stage consumers are making purchase decisions. 
PRESS

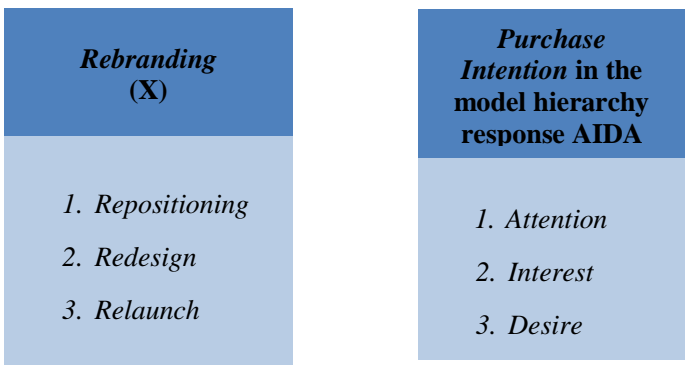

Fig. 2. Paradigm Research

Based on the concept of AIDA in Figure 1.2 which is an indicator of consumer purchase intention include Attention, Interest and Desire. The disuse of one element AIDA last stages Action because it is not part of the stage of purchase intention, but has entered the stage of purchasing decisions which according to Kinnear and Taylor cited by Thamrin (2013, p. 142) "purchase intention is part of a component of consumer behavior in consuming attitude, the tendency of respondents to act before a purchase decision is actually implemented". Likewise with indicators of rebranding that there are four stages of the process of rebranding includes Repositioning, Renaming, Redesign and Relaunch. The disuse of one of the stages: stage Renaming rebranding process, because the companies surveyed do not perform the process, but only three-stage process, namely Repositioning, Redesign and Relaunch [11].

The hypothesis of this study is there "rebranding influence on purchase intention"

\section{RESEARCH METHOD}

The method used in this research is descriptive and verification using a quantitative approach. Descriptive research describes an overview of rebranding (X), which includes repositioning, redesign and relaunch also an overview of the purchase intention (Y) using a hierarchical approach begins responses of attention, interest, and desire. This study examined the relationship between rebranding $(\mathrm{X})$ with purchase intention (Y).

The population of this research is Student Program Management Studies UPI forces 2012-2015 a total of 295 people (data by Sec. Academic FPEB UPI).

The sample in this study is an active student of Management Studies Program UPI class of 2012 to 2015 which involved or participating in Kamis Senja event because King Thai Tea has several times become a sponsorship partner community activities UPI Management (IMAGE) conducted on February 26, 2015 and 5 November 2015 in which King Thai Tea as sponsorship partners eliminate its product for anyone who participates in the event by simply uploading photos to social media products. In determining the number of samples, researchers with the calculation formula Slovin, Then the sample is obtained as many as 170 respondents. The sampling used was probability sampling. In use probability sampling proportionate stratified random sampling. So, in this technique researchers will look for respondents with stratum proportional Student Management Studies Program 2012-2015 UPI forces.

The results were analyzed using SPSS version 17.0 to establish the validity and reliability of measuring instruments. Testing the validity of the instrument was conducted on 30 respondents. Validity coefficients on a scale rebranding (X) ranging from 0.475 to 0.739 with a significance level of 0.374 rtabel to be valid. Validity coefficient scale purchase intention (Y) ranging from 0.444 to 0.850 with a significance level of 0.374 which is in the valid criteria. The coefficient of reliability scale rebranding $(\mathrm{X})$ is at 0,757 and purchase intention $(\mathrm{Y}) 0,865$ proved to be greater than the minimum reliability Cronbach's Alpha amounting to 0,700. Therefore, the overall statement items contained in the questionnaire studies have been reliable in accordance with the reliability test.

Data analysis method used is parametric statistical test simple linear regression. Processing data using the program Statistical packages for Social Sciences (SPSS) version 17.0 for Windows.

\section{RESULTS AND DISCUSS}

To test statistic in this study used a simple linear regression analysis approach. The data used as the independent variable (X) is rebranding as well as the dependent variable $(\mathrm{Y})$ is purchase intention also these variables has been transformed into a scale of measurement interval with the next MSI used for calculations and hypothesis testing.

\section{A. Normality Test Results}

Normality test on the regression model was used to test whether the residual value consisting of grains questions normally distributed or not. The data is said to have a normal deployment, if the deployment of the data follow a diagonal line from the lower left to the upper right. In this research will be rebranding the data distribution (independent variable) and purchase intention (dependent variable). To detect normality, use normal probability plots, can be seen in the following figure:
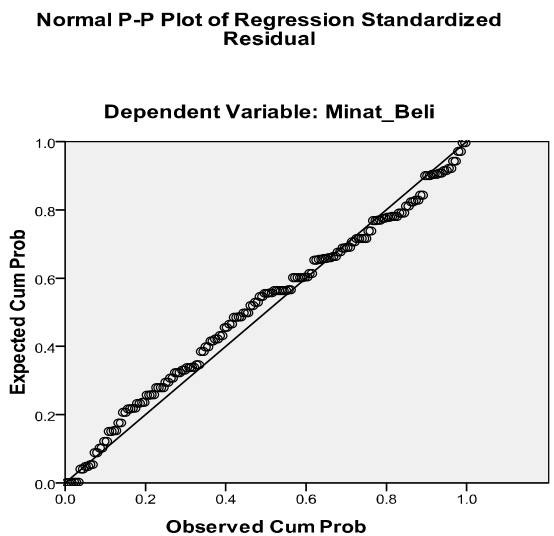

Source: Data Processing Using SPSS 17.0, 2016

Fig. 3. Normality Test 


\section{PRESS}

Based on Figure 1. 3 it can be concluded that the normal distribution of data as it spread around the diagonal line from the lower left to the upper right, then the regression model showed that normality requirements are met.

\section{B. Correlation coefficient}

The correlation coefficient is used to measure the magnitude of the relationship, or in other words knowing relationship between rebranding (independent variable) with purchase intention (dependent variable). In this study the authors used correlation analysis product moment correlation analysis is technically assisted with SPSS 17.0 software for windows:

\section{TABLE II. OUTPUT CORRELATION}

\section{Correlations}

\begin{tabular}{|l|l|l|l|}
\hline \multicolumn{1}{|c|}{} & & \multicolumn{1}{c|}{$\begin{array}{c}\text { purchase } \\
\text { intention }\end{array}$} & Rebranding \\
\hline \multirow{2}{*}{$\begin{array}{l}\text { Pearson } \\
\text { Correlation }\end{array}$} & purchase intention & 1.000 & .713 \\
\cline { 2 - 4 } & Rebranding & .713 & 1.000 \\
\hline \multirow{2}{*}{ Sig. (1-tailed) } & purchase intention &. & .000 \\
\cline { 2 - 4 } & Rebranding & .000 &. \\
\hline \multirow{2}{*}{$\mathrm{N}$} & purchase intention & 170 & 170 \\
\cline { 2 - 4 } & Rebranding & 170 & 170 \\
\hline
\end{tabular}

The correlation coefficient between the rebranding with purchase intention amounted to 0.713 and the significance of 0.000 . Significance value of $<0.05$, then $\mathrm{H} 0$ rejected and $\mathrm{H} 1$ accepted. Thus, it can be said that there is a significant influence of rebranding with purchase intention.

Based on the interpretation of correlation values according to (Sugiyono, 2012, p. 184), then the correlation values 0,713 is in the interval of 0,600 to 0,799 which belong to the high degree of correlation [12].

\section{Simple Regression Analysis}

The study consists of one independent variable so that the regression analysis technique used is a simple linear regression (simple). Simple regression analysis is used to determine how the dependent variable $(Y)$ purchase intention may be predicted by the independent variable $(\mathrm{X})$ rebranding or predictor individually. The following Table III which describes the results of a regression analysis of the data processing SPSS 17.0 for Windows:

\section{TABLE III. OUTPUT COEFFICIENT OF DETERMINATION}

Model Summary ${ }^{b}$

\begin{tabular}{|l|l|l|l|l|}
\hline Model & \multicolumn{1}{|c|}{$\mathbf{R}$} & $\begin{array}{c}\text { R } \\
\text { Square }\end{array}$ & $\begin{array}{c}\text { Adjusted R } \\
\text { Square }\end{array}$ & $\begin{array}{c}\text { Std. Error of } \\
\text { the Estimate }\end{array}$ \\
\hline 1 & $\begin{array}{l}.713 \\
\mathrm{a}\end{array}$ & .508 & .505 & 4.66173 \\
\hline \multicolumn{2}{|l|}{ a. Predictors: (Constant), Rebranding } \\
\hline \multicolumn{2}{|l|}{ b. Dependent Variable: purchase intention } \\
\hline
\end{tabular}

b. Source: Results of data processing using SPSS 17.0 for Windows, 2016
The coefficient of determination is generated by linear regression analysis (simple) is

$$
\begin{aligned}
\mathrm{KD} & =\mathrm{r}^{2} \times 100 \% \\
& =(0,713)^{2} \times 100 \% \\
& =50,83 \%
\end{aligned}
$$

Which means that purchase intention King Thai Tea beverage products affected by the rebranding of $50,8 \%$, while the rest of $100 \%-50,8 \%=49,2 \%$, influenced by other factors

\begin{tabular}{|c|c|c|c|c|c|c|}
\hline \multicolumn{7}{|c|}{ Coefficients $\mathrm{s}^{\mathrm{a}}$} \\
\hline & \multirow[b]{2}{*}{ Model } & \multicolumn{2}{|c|}{$\begin{array}{l}\text { Unstandardized } \\
\text { Coefficients }\end{array}$} & \multirow{2}{*}{\begin{tabular}{|c|} 
Standardized \\
Coefficients
\end{tabular}} & \multirow[b]{2}{*}{$\mathbf{t}$} & \multirow[b]{2}{*}{ Sig. } \\
\hline & & B & Std. Error & & & \\
\hline \multirow{2}{*}{1} & (Constant) & 11.201 & 1.901 & & 5.893 & .000 \\
\hline & Rebranding & .744 & .056 & .713 & 13.181 & .000 \\
\hline
\end{tabular}
not examined by the authors.

TABLE IV. REGRESSION COEFFICIENTS OUTPUT

c. Source: Data Processing Using SPSS 17.0, 2016

According to Table IV, resulted the regression equation:

$$
\mathrm{Y}=11.201+0,744 \mathrm{X}
$$

From the equation, the constant is 11.201 which is show that if there is not rebranding, purchase intention on King Thai Tea is 11.201. While, coefficient regression of rebranding is 0,744 , which means that any gains in rebranding a number of factors or one unit, there will be an increase in purchase intention at 0.744 .

\section{Hypothesis Test Results}

Hypothesis test is used to determine the level of significance of the correlation coefficient between independent variable with the dependent variable. Hypothesis test is $t$ test. $T$ tests were performed to test the hypothesis of a correlation between the independent variable and the dependent variable individually. The following are the

\begin{tabular}{|c|c|c|c|c|c|c|}
\hline & \multirow[b]{2}{*}{ Model } & \multicolumn{2}{|c|}{$\begin{array}{l}\text { Unstandardized } \\
\text { Coefficients }\end{array}$} & \multirow{2}{*}{$\begin{array}{c}\text { Standardized } \\
\text { Coefficients }\end{array}$} & \multirow[b]{2}{*}{$\mathbf{t}$} & \multirow[b]{2}{*}{ Sig. } \\
\hline & & $B$ & Std. Error & & & \\
\hline \multirow[t]{2}{*}{1} & (Constant) & 11.201 & 1.901 & & 5.893 & .000 \\
\hline & Rebranding & .744 & .056 & .713 & 13.181 & .000 \\
\hline \multicolumn{7}{|c|}{ a. Dependent Variable: Purchase intention } \\
\hline
\end{tabular}
significant value of $t$ test:

\section{TABLE V. SignificAnCE VAlue T TEST}

Coefficients

To test the hypothesis of partial comparet $\mathrm{t}_{\text {count }}$ with $\mathrm{t}_{\mathrm{table}}=$ 1,65397. $\mathrm{t}_{\text {count }}$ The resulting variable rebranding is 13.181 , , then $\mathrm{t}_{\text {count }}>\mathrm{t}$ table $(13.181>1.653)$, meaning that there are significant rebranding variable $(\mathrm{X})$ on purchase intention $(\mathrm{Y})$ 
King Thai Tea beverage products. Rebranding variable probability value 0.05 is well below 0,000 so that through this method is also found at a significance level of 5\% rebranding variable positive and significant effect on the variable purchase intention King Thai Tea beverage products.

\section{CONCLUSION}

Overview performance rebranding conducted by King Thai Tea in the perceptions of 170 students of Management Studies 2012-2015 UPI forces are at intervals of high continuum with a score of 5945. This illustrates that the rebranding conducted by King Thai Tea in terms of strengthening brand identity as Thai Tea larger and characterize young people can plug memorable characters by the majority of student respondents forces UPI Management Program 2012-2015. Indicators contained in rebranding variable in this research is repositioning, redesign, and relaunching. As follows, inferred based on the highest contribution and the lowest by respondents:

Repositioning indicator is an indicator that contributes the highest to variable rebranding to obtain an average score greatest. This is because the creation of the position or a new meaning that is carried out by King Thai Tea with having more fresh brand than ever, it is easier to get a drink product, a jug efforts of King Thai Tea brand positioning Thai Tea as a beverage urban youth in the minds of respondents.

Relaunch indicator is an indicator that the lowest contribute to variable rebranding because it has the lowest average score. This was caused because information or publications not delivered both on brand new beverage products, promotional packages and other things evenly and structured according to the responses of the respondents.

Other indicators that influence is the redesign. The result of the acquisition the average score is not much different between the indicators, provides a conclusion regarding the views of students of class 2012-2015 UPI Management on the performance of rebranding conducted by King Thai Tea that the efforts of King Thai Tea succeeded in showing a new identity and is able to placing as one brand Thai Tea larger by keeping the standards at the highest level, different, unique and well characterized.

Overview purchase intention on King Thai Tea beverage products in the perceptions of 170 students of Management Studies 2012-2015 UPI forces are at intervals of high continuum with a score of 6685. This illustrates that the respondents have interest in buying power over King Thai Tea beverage products. Indicators contained the variable purchase interest in this research, namely attention, interest, and desire. As follows, inferred based on the highest and lowest contributions according to the respondents:

Attention indicator is an indicator that contributes the highest to variable purchase intention because it has the largest average scores. That is because the high curiosity of respondents due to the trend of Thai Tea itself and King Thai Tea became an iconic brand when it comes to Thai Tea beverage products that continue to be talks environment young people.
Indicators of interest is an indicator of the lowest contribute to variable purchase intention because it has the lowest average score. This is because information beverage products that try to offer King Thai Tea not give special interest for the majority of respondents also respondents confronted with various brands of Thai Tea beverage products other (competitors).

Other indicators that influence is desire. Obtaining an average score that was not much difference, to the conclusion that the respondents give good attention, interest and also interest in buying King Thai Tea beverage products for a variety of unique products or benefits provided.

Rebranding variables affect the variable interest in purchasing products King Thai Tea beverages. The positive influence means that any gains on variable rebranding occurs, there will be also an increase in purchase intention. This is consistent with previous research by LIU, SW et al. (2009), that the rebranding strategy has been the usual practice for marketers to reach the goal. By changing the brand of visual elements such as color and logo aims to create a new brand association and encourage customer purchase intention [13].

Based on the research conducted on Student of Management Studies Program UPI forces 2012-2015, indicating there is significant impact between rebranding variable with purchase intention variable on King Thai Tea beverage products. Interpretation of the correlation coefficient in the previous discussion showed a high coefficient values or at the high impact.

\section{SUGGESTION}

Researchers realized the many limitations to this study. Therefore, suggestions for further research are expected to do research on purchase intention by using other factors that may affect that company always strives to continue to keep the standards at the highest level in a variety of marketing strategies. It is also will enrich the knowledge about the management of marketing and consumer behavior as well as an input for King Thai Tea to increase purchase intention until the volume of sales through dynamic marketing strategy, continue to change with the circumstances of the times. The rest, it would be interesting if further research was sharpened with a variety of other variables such as, event marketing, brand image and brand awareness to influence purchase intention.

\section{REFERENCES}

[1] Hartono. Menperin: Triwulan I tahun 2015, Industri Makanan dan Minuman Capai 8,16\%. Available from URL: http://www.kemenperin.go.id/. Accessed May 26, 2015.

[2] Mixmarcomm. Indonesia Rilis Hasil Riset Preferensi Produk Home Consumption. Available from URL: http://mix.co.id/brandinsight/research/kantar-worldpanel-indonesia-rilis-hasil-riset-preferensiproduk-home-consumption. Accessed December 15, 2014.

[3] SWA. Sukses Dianta dan Ryanda Jualan Air The Khas Thailand. Available from URL: http://swa.co.id/youngsterinc/headline/suksesdianta-dan-ryanda-jualan-air-teh-khas-thailand. Aceessed October 30, 2013. 
[4] Kontan.co.id. Menyeruput Tezeki Dari The Khas Thailand. Available from URL: http://peluangusaha.kontan.co.id/news/menyeruput-tezekidari-teh-khas-thailand. Accessed February 23, 2015.

[5] Kotler, Philip \& Kevin L. Keller. Marketing Management, 15th edition. New Jersey: Pearson Prentice Hall, Inc, 2016.

[6] Muzellec, Laurent. Dogan, Mans. Dan Lambkin, Mary. "Corporate Rebranding- An Exploratory Review". Irish Marketing Review. 16, 2003, pg.31-40.

[7] Muzellec, Laurent dan Lambkin, Mary. "Corporate Rebranding: Destroying, Transferring or Creating Brand Equity?". European Journal of Marketing. Emerald Group Publishing Limited. 40, 2006, pg.7-8.
[8] Ceritaperut.com. Top 10 Minuman Hitz Bandung. Available from URL: http://ceritaperut.com/top-list/view/185. Accessed October 6, 2015.

[9] Kotler, Philip. dan Armstrong, Gary. Principles of Marketing 14th E. Upper Saddle River, New Jersey: Pearson Prentice-Hall, 2014.

[10] Kotler, Philip, Kevin Lane Keller. Marketing Management. Jakarta : Erlangga, 2012.

[11] Abdullah, Thamrin dan Francis Tantri. Manajemen Pemasaran. cet. II. Jakarta: PT RajaGrafindo Persada, 2013.

[12] Sugiyono. Metode Penelitian Kuantitatif, Kualitatif dan R\&D. Bandung: Alfabeta, 2012.

[13] LIU, S.W., Dr. Tang, Esther. Factors Influencing Effective Rebranding Strategy. The Hong Kong Polytechnic University. ANZMAC, 2009. 